\title{
Pelatihan Pembuktian Perselisihan Hasil Pemilu Di Kota Bengkulu
}

\author{
Amancik ${ }^{1}$, Putra Perdana Ahmad Saifulloh ${ }^{1,{ }^{*}}$, Beni Kurnia Illahi ${ }^{1}$, Sonia Ivana Barus ${ }^{1}$ \\ ${ }^{1}$ Fakultas Hukum; Universitas Bengkulu; JI. WR. Supratman, Kandang Limun; \\ Bengkulu, 38373, Telp +62-736-21170 / Fax +62-736-2210; e-mail: \\ amancikangkadi@gmail.com, putrappas@unib.ac.id, benikurnia@unib.ac.id, \\ soniaivana@unib.ac.id \\ *Korespondensi: e-mail: putrappas@unib.ac.id
}

Submitted: 07/09/2020; Revised: 8/01/2021; Accepted: 15/01/2021; Published: 29/01/2021

\begin{abstract}
The Constitutional Court has the authority to protect the constitutional rights of citizens and provide interpretations of the constitution, ideally in an election which is a political contestation that is built up by many things in its implementation. The Constitutional Court's function is to keep the Election in line with Election Principles which are regulated by Positive Law. Based on the above assumptions, it is worth discussing whether the process of proving PHPU in the Constitutional Court has been able to guarantee the implementation of an overly judicial election, or simply whether the proof of PHPU is ideal. This activity is about providing understanding to Participants of Evidence and Evidence Tool on Election Result Disputes; Providing understanding to Participants regarding updated matters regarding the Legal Evidence of Election Result Dispute; and especially for Lecturers as a means of Community Service which is part of the Tri Dharma of Higher Education.
\end{abstract}

Keywords: Evidence, Evidence Tool, Election Result Disputes

\begin{abstract}
Abstrak
Mahkamah Konstitusi memiliki kewenangan untuk melindungi hak konstitusional warga negara dan memberikan interpretasi terhadap konstitusi, idealnya dalam Pemilu yang merupakan kontestasi politik dipengaruhi oleh banyak hal dalam pelaksanaanya. MK berfungsi untuk menjaga agar Pemilu sejalan dengan Asas Luber dan Jurdil sebagaimana yang diatur Hukum Positif. Berdasar pada anggapan di atas, maka patutlah didiskusikan, apakah proses pembuktian PHPU di MK telah mampu menjamin terlaksanya Pemilu yang Luber Jurdil, atau sederhananya apakah Pembuktian PHPU tersebut telah ideal. Kegiatan ini dimaksudkan untuk memberikan pemahaman kepada Peserta tentang Pembuktian dan Alat Bukti Perselisihan Hasil Pemilu; Memberi pemahaman kepada Peserta tentang hal-hal update tentang Pembuktian Hukum Acara PHPU; dan khusus Dosen sebagai sarana Pengabdian Kepada Masyarakat yang merupakan bagian dari Tri Dharma Perguruan Tinggi.
\end{abstract}

Kata kunci: Pembuktian, Alat Bukti, Perselisihan Hasil Pemilu

\section{Pendahuluan}

Perkembangan model perselisihan hasil Pemilu (Untuk Selanjutnya Penulis sebut PHPU) di Mahkamah Konstitusi (Untuk Selanjutnya Penulis sebut MK) dari kuantitas penentuan angka-angka hasil Pemilihan Umum (Untuk Selanjutnya Penulis sebut Pemilu) yang diperoleh kontestan Pemilu, menjadi kualitas pelaksanaan Pemilu. MK juga menilai substansi pelaksanaan Pemilu apakah sudah sejalan dengan asas-asas Pemilu, Luber dan Jurdil (Ansori, 
2017). Asas Luber (langsung, umum, bebas, dan rahasia) dan Jurdil (jujur dan adil) merupakan asas Pemilu sebagaimana termaktub dalam Pasal 22E ayat (1) UUD 1945 (Supriyadi \& Kasim, 2020). MK sebagai Penyelenggara Kekuasaan Kehakiman tentunya bertujuan menegakkan keadilan substantif, sehingga apabila terdapat Tahapan Pemilu yang tidak sesuai dengan asasasas pemilu, MK dapat memerintahkan KPU untuk dilakukan penghitungan atau Pemungutan suara ulang (Tim Pengajar, 2019).

Dinamika putusan MK yang awalnya hanya mempermasalahkan kuantitatif berkembang menjadi mengkaji permasalahan kualitatif Implementasi Pemilu yang bisa dilihat dalam Putusan No.062/PHPU-B-II/2004. Dalam Perkara yang diajukan oleh Pasangan Capres dan Cawapres pada Pilpres 2004 sebagai upaya MK untuk menjaga Pemilu agar tetap berada di jalur Asas Luber dan Jurdil yang digariskan Konstitusi. Adapun pertimbangan Hukum MK dalam Perkara $A$ Quo, yaitu (Tim Pengajar, 2019):

MK sebagai the guardian of constituttions diberikan amanah oleh Konstitusi menjaga agar Penyelenggaraan Pemilu dilakukan dengan berpegang teguh pada asas Luber dan Jurdil.

Menimbang beberapa permasalahan yang sifatnya kualitatif sebagaimana didalilkan Pemohon pada dasarnya sudah diberikan sarana penyelesaiannya dalam UU Pilpres, pada semua tahapan dan jenjang penyelenggaraan Pemilu, Prosedur yang dimaksud akan terlaksana dengan baik apabila terdapat keberatan dari peserta Pemilu ditanggapi dan ditangani oleh Penyelenggara dan Penegak Hukum Pemilu.

Menimbang bahwa kedudukan MK dalam PHPU bukan menjadi lembaga banding, kasasi atau Peninjauan Kembali dari macam-macam sengketa Pemilu diluar MK yang pada dasarnya sudah mempunyai prosedur penyelesaiannya masing-masing. Dalam perkara Pemilu, MK adalah Penyelenggara Kekuasaan Kehakiman tingkat final and binding tershadap sengketa hasil yang ditetapkan dan diumumkan KPU [vide Pasal 85 dan Pasal 68 UU Pilpres, juga Pasal 74 ayat (2) huruf b dan Pasal 75 UUMK], yang pada dasarnya merupakan problem yang bersifat kuantitatif, yaitu signifikansi angka hasil Pemilu yang berdampak pada kemenangan pasangan calon tertentu. Dalam permasalahan kualitatif yang menjadi concern MK apabila terdapat pelanggaran terhadap asas-asas Pemilu yang ditentukan oleh Konstitusi.

Dalam Pandangan MK Terhadap PHPU, MK bukanlah hanya sebagai lembaga banding kasasi atau PK dari sengketa Pemilu yang berskala lokal dan sektoral terkait pidana dan sengketa administrasi kepemiluan (Gubernur, 2016). Kedudukan MK dalam PHPU adalah Penyelenggara Kekuasaan Kehakiman tingkat final and binding perselisihan hasil Pemilu, MK yang menjamin konstitusionalitas pelaksanaan Pemilu (Iza Rumesten RS, 2014). Sehingga permasalahan kualitatif yang menjadi concern MK apabila terdapat pelanggaran terhadap asasasas Pemilu yang ditentukan oleh Konstitusi. Dalam Putusan MK No.062/PHPU-B-II/2004 menyebutkan MK yang merupakan The Guardian Of Constituttions memiliki kewajiban menjaga pelaksanaan pemilu agar berjalan sebagaimana amanah Konstitusi. (Kurniawan, 2011). Hal itulah yang berimplikasi pada Putusan-putusan MK yang memerintahkan Penyelenggara 
Pemilu, baik itu KPU, KPU provinsi, KPU kabupaten/kota, maupun KIP Aceh untuk dilakukan penghitungan, bahkan pemungutan suara ulang (Tim Pengajar, 2019).

Sebelumnya, Pileg dan Pilpres pernah dilaksanakan secara terpisah, yakni pada Pemilu tahun 2004, 2009, dan 2014. Namun, Pasca Putusan MK No.14/PUU-XI/2013, terjadi pemisahan waktu pelaksanaan kedua pemilu tersebut dinyatakan inkonstitusional karena bertentangan dengan Pasal 22E ayat (1 dan 2) UUD 1945, sehingga mulai pada tahun 2019, kedua pemilu tersebut harus dilaksanakan secara serentak. Putusan tersebut, selanjutnya dipertegas dengan lahirnya UU No.7 Tahun 2017 tentang Pemilu. PHPU pada dasarnya menjadi salah satu permasalahan pemilu yang lazim terjadi di Indonesia. Permasalahan lainnya adalah tindak pidana pemilu, pelanggaran administrasi pemilu, dan sengketa yang terjadi di dalam penyelenggaraan pemilu (Seran, 2019).

Secara normatif, maksud dari PHPU dapat dipahami melalui Pasal 473 ayat (1) UU No.7 Tahun 2017 tentang Pemilu. Sebagaimana ditegaskan oleh pasal tersebut, "PHPU adalah PHPU antara KPU dan Peserta Pemilu Tentang penetapan perolehan suara hasil Pemilu secara nasional'. Peserta Pemilu dapat difahami yaitu Parpol (untuk Pemilu anggota DPR, DPRD Provinsi, dan DPRD kabupaten/kota atau biasa disebut juga sebagai Pemilihan Anggota Legislatif atau Pileg), perseorangan untuk Pemilu anggota DPD, dan pasangan calon presiden dan wakil presiden yang diusung oleh parpol atau koalisi parpol untuk Pilpres. Untuk Pileg, PHPU yang disengketakan ke MK adalah penetapan perolehan suara yang dapat mempengaruhi perolehan kursi Peserta Pemilu. Jika dalam Pilpres, PHPU memengaruhi penetapan hasil Pilpres (Seran, 2019).

Kewenangan MK dalam memutus PHPU diatur dalam Pasal 24C ayat (1) UUD 1945, dan Pasal 10 ayat (1) UU Nomor 24 Tahun 2003 tentang MK jo Pasal 29 ayat (1) huruf d UU No.48 Tahun 2009 Tentang Kekuasaan Kehakiman. Pasal 10 ayat (1) UU MK mengatur ketentuan seperti dalam Konstitusi, yaitu: (Bambang Sutiyoso \& Sri Hastuti Puspitasari, 2005):

MK memiliki empat kewenangan dan satu kewajiban MK, yaitu: mengadili pada tingkat pertama dan terakhir yang putusannya bersifat final and binding dalam menguji UU terhadap UUD 1945, memutus sengketa UUD 1945, memutus pembubaran parpol, dan memutus PHPU.

Sesuai dengan Pasal 22E UUD 1945, pemilu bertujuan untuk memilih anggota DPR, DPD, DPRD, dan Presiden dan Wapres. Maka itu PHPU yang menjadi Kewenangan MK adalah PHPU anggota DPR, DPRD, DPD, dan Presiden dan Wapres sebagaimana termaktub dalam Pasal 74 ayat (2) UU MK. Namun telah terjadi perluasan makna Pemilu yang merupakan wewenang MK. Dinamika Perluasan Makna Pemilu terjadi akibat Putusan MK No.072073/PUU-II/2004, dimana MK menyatakan Pilkada merupakan rezim Pemilu (Tim Pengajar, 2019).

Putusan ini mempengaruhi pembentuk undang-undang yang selanjutnya menjadikan Pilkada yang Namanya berubah menjadi Pemilukada merupakan rezim dari Pemilu melalui UU No.22 Tahun 2007 tentang Penyelenggara Pemilu. Perubahan Pemilukada dari rezim pemerintahan daerah ke rezim Pemilu kemudian diperkuat oleh UU No.12 Tahun 2008 tentang 
Revisi Terbatas UU No.32 Tahun 2004 tentang Pemerintahan Daerah. Dalam Pasal 236C UU a quo terjadi penyerahan wewenang secara legalistik dalam memutus PHPU Kepala Daerah (PHPUD) dari Mahkamah Agung (MA) ke MK paling lambat 18 bulan sejak diundangkannya UU a quo. penyerahan wewenang secara legalistik dalam memutus PHPUD dari MA ke MK secara resmi dilakukan oleh Ketua MA, Bagir Manan dan Ketua MK, Moh. Mahfud MD pada Tanggal 29 Oktober 2008. Sejak itu, wewenang memutus PHPUD menjadi wewenang MK. Jadi, jenis Pemilu yang perselisihannya menjadi wewenang MK untuk mengadili dan memutus, adalah: (Tim Pengajar, 2019): a) Pemilu Legislatif yang meliputi pemilu anggota DPR, DPD, dan DPRD; b) Pemilu Presiden dan Wapres (Pilpres); dan c) Pemilu Kepala Daerah (Pemilukada).

Penyelesaian PHPU yang menjadi kewenangan MK, dewasa ini banyak menuai perdebatan. Mulai dari jangka waktu persidangan yang di anggap tidak cukup untuk memenuhi dan mendapatkan putusan yang adil, sebagaimana motto MK sebagai lembaga peradilan yang mengutamakan keadilan substantif dalam setiap putusannya. Hingga pada proses pembuktian PHPU yang seharusnya tidak hanya terjebak pada diksi "perselisihan hasil", namun juga secara mendalam melihat "proses yang mempengaruhi hasil". Sehingga sengketa PHPU di MK dapat membuktikan bahwa pelaksanaan Pemilu telah atau tidak memenuhi asas Luber Jurdil sebagai nyawa dalam pelaksanaan Pemilu. Kendati demikian, haruslah diakui bahwa bukanlah perkara mudah untuk menemukan formulasi pembuktian yang tepat dalam sengketa PHPU di MK, sehingga diharapkan dapat menemukan fakta real dari pelaksanaan Pemilu yang ada. MK sebagai wajah konstitusi di Indonesia dengan kewajibannya untuk melindungi dan memberikan interpretasi terhadap konstitusi (the guardian of constitution and the sole interpretter of constitution), idealnya haruslah menyadari bahwa Pemilu sebagai kontestasi politik dipengaruhi oleh berbagai problem dalam penyelenggaraannya. Berdasar pada anggapan di atas, maka patutlah diajukan pertanyaan, apakah proses pembuktian PHPU di MK telah mampu menjamin terlaksanya Pemilu yang Luber Jurdil?, atau sederhananya apakah pembuktian PHPU tersebut telah ideal?.

Berdasarkan uraian tersebut diatas, pengabdi berupaya agar kegiatan pengabdian masyarakat ini dapat memberikan kontribusi bagi Mitra Pengabdian Kepada Masyarakat ini, yaitu Komunitas Republik Celoteh Hukum (RECEH); Organisasi Mahasiswa Intra dan Ekstra Kampus di Kota Bengkulu; Organisasi Kepemudaan Bengkulu; dan Organisasi Pemuda Daerah Bengkulu dalam memahami Pembuktian dan Alat Bukti PHPU di MK. Di samping itu agar Peserta Pelatihan ini dapat menginfomasikan Pembuktian dalam Hukum Acara PHPU di MK.

\section{Metode Pelaksanaan}

Kegiatan Pengabdian Kepada Masyarakat (PKM) ini dilaksanakan di Warung Snack and Drink Jl. Jati, Sawah Lebar, Ratu Agung, Bengkulu, pada hari Senin, tanggal 30 Juni 2020 Pukul 18.30 WIB sampai dengan Pukul 22.30 WIB. Model PKM adalah Pelatihan yang diselenggarakan dengan metode diskusi dua arah dan "Sersan (Serius Tapi Santai)". Dalam 
mengukur pemahaman peserta terhadap materi yang disampaikan, diserahkan kuisioner kepada peserta pada saat sebelum kegiatan dilaksanakan. Hal ini diperlukan agar pelaksanaan dari penyuluhan ini dapat berjalan dengan efektif.

\section{Hasil dan Pembahasan}

Materi yang Pengabdi presentasikan adalah Pembuktian dan Alat Bukti di MK. Dalam Materi ini Pengabdi mensajikan mengenai Pembuktian dalam Hukum Acara PHPU di MK. Berikut adalah kesimpulan adalah paparan pengabdi.

Pasal 1 ayat (2) UUD 1945 menyatakan Indonesia merupakan negara yang menempatkan kedaulatan rakyat merupakan kedaulatan tertinggi, dan kedaulatan itu dilaksanakan berdasarkan Konstitusi. Berdasar pada kerangka konstitusional tersebut, maka Indonesia meletakkan Pemilu sebagai salah satu pilar dalam penyelenggaraan negara. Pelaksanaan Pemilu haruslah merujuk pada asas atau prinsip yang melekat di dalamnya, yaitu Luber Jurdil sebagaimana penegejawantahan dari amanat Pasal 22E ayat (1) UUD 1945. (Kosmas Ebu, dan Mauritsius, 2009). Pelaksanaan Pemilu tidak hanya ditentukan dari terlaksananya pemungutan suara semata, namun juga efektivitasnya pengawasan, penegakan hukum serta penyelesaian perselisihan. Setiap pelanggaran dapat ditangani dengan baik dan diberikan hukuman sebagaimana hukum positif dan setiap PHPU dapat diselesaikan dengan imparsial. Hasil pemilu yang merupakan penetapan hasil akhir rekapitulasi suara yang diumumkan secara resmi oleh KPU dan acapkali tidak memuaskan peserta pemilu yang kalah (Ni'matul Huda, 2008).

Secara umum, penyelesaian PHPU (Presiden, Wakil Presiden, DPR, DPD, DPRD dan Kepala Daerah) dinaungi oleh Mahkamah Konstitusi (MK). Hal ini berdasar pada MK yang berfungsi sebagai pengawal konstitusi. Penyelesaian PHPU yang merupakan kewenangan MK, dewasa ini banyak menuai perdebatan. Mulai dari jangka waktu persidangan yang di anggap tidak cukup untuk memenuhi dan mendapatkan putusan yang adil, sebagaimana motto MK sebagai lembaga peradilan yang mengutamakan keadilan substantif dalam setiap putusannya. Hingga pada proses pembuktian PHPU yang seharusnya tidak hanya terjebak pada diksi "perselisihan hasil", namun juga secara mendalam melihat "proses yang mempengaruhi hasil". Sehingga sengketa PHPU di MK dapat membuktikan bahwa pelaksanaan Pemilu telah atau tidak memenuhi asas Luber Jurdil sebagai nyawa dalam pelaksanaan Pemilu. Kendati demikian, haruslah diakui bahwa bukanlah perkara mudah untuk menemukan formulasi pembuktian yang tepat dalam sengketa PHPU di MK, sehingga diharapkan dapat menemukan fakta real dari pelaksanaan Pemilu yang ada. MK sebagai wajah konstitusi di Indonesia dengan kewajibannya untuk melindungi dan memberikan interpretasi terhadap konstitusi (the guardian of constitution and the sole interpretter of constitution), idelanya haruslah menyadari bahwa Pemilu sebagai kontestasi politik tidak bisa lepas dari berbagai problem dalam pelaksanaanya. (Jimly Asshiddiqie, 2005). 
Dalam PHPU, alat bukti sebagaimana termaktub dalam Pasal 10 Peraturan MK No.16 tahun 2009, terdiri dari surat atau tulisan, keterangan saksi, keterangan ahli, keterangan para pihak, petunjuk dan informasi elektronik dan/atau dokumen elektronik.

Adapun Alat bukti surat atau tulisan sebagaimana termaktub dalam Pasal 11 PMK No.16 Tahun 2009 adalah yang mempunyai keterkaitan langsung dengan objek PHPU yang sedang disidangkan di MK. Alat bukti surat atau tulisan adalah sebagai berikut: a) berita acara dan salinan pengumuman hasil pemungutan suara parpol peserta Pemilu dan calon anggota DPR, DPD, dan DPRD di TPS; b) berita acara dan salinan rekapitulasi jumlah suara parpol peserta Pemilu dan calon anggota DPR, DPD, dan DPRD dari PPK; c) berita acara dan salinan rekapitulasi hasil penghitungan suara parpol peserta Pemilu dan calon anggota DPR, DPD, dan DPRD dari KPU kabupaten/kota; d) berita acara dan salinan penetapan hasil penghitungan suara anggota DPRD kabupaten/kota; e) berita acara dan salinan rekapitulasi hasil penghitungan suara dari KPU provinsi; f) berita acara dan salinan penetapan hasil penghitungan suara anggota DPRD provinsi; g) berita acara dan salinan rekapitulasi hasil penghitungan suara dari KPU; h) berita acara dan salinan penentapan hasil penghitungan suara secara nasional anggota DPR, DPD, dan DPRD dari KPU; i) salinan putusan pengadilan yang telah memperoleh kekuataan hukum tetap yang mempengaruhi perolehan suara partai politik peserta Pemilu dan calon anggota DPR, DPD, DPRD provinsi, dan DPRD kabupaten/kota; dan j) dokumen tertulis lainnya.

Adapun Tahapan persidangan di MK, terdiri dari a) mendengarkan permohonan; b) jawaban termohon; c) keterangan pihak terkait; d) pembuktian oleh pemohon, termohon, pihak terkait; dan e) kesimpulan.

Apabila dipandang perlu, di dalam proses persidangan MK dapat menetapkan putusan sela sebelum putusan akhir. Putusan sela tersebut didasari permohonan Pemohon yang merasa hak-hak konstitusionalnya akan dirugikan apabila menunggu putusan akhir MK. Jika MK merasa alasan Pemohon beralasan, maka MK dapat menjatuhkan putusan sela terkait perkara tersebut.

Dalam PHPU, MK akan memberi tenggang waktu yang tidak lama untuk persidangan selanjutnya. Hal tersebut terkait dengan batas waktu penyelesaian perkara PHPU yang dibatasi 30 hari setelah perkara terdaftar dalam BRPK. Para pihak dalam siding PHPU Diberi Ruang untuk sama-sama membuktikan dalilnya dalam pembuktian dan menghadirkan alat bukti. Kebiasaan di MK, Hakim akan lebih mendengar dan mempertimbangkan para pihak yang mampu menghadirkan alat bukti yang sahih dalam persidangan. Apabila masing-masing kertas perhitungan tersebut asli dan kredibel, maka Hakim juga mempertimbangkan fakta persidangan yang $m$,enjadi landasan hakim dalam membuat Putusan.

Dalam Sidang MK diberikan ruang oleh MK bagi Pihak Terkait dan Para Saksi untuk menerangkan apa yang mereka alami, dengar dan rasakan yang relevan dengan perkara yang sedang diperiksa MK. Para pihak dalam sidang MK juga diberi ruang untuk menghadirkan Ahli sebagai seseorang yang dianggap memiliki keahlian dari bangku Pendidikan formal maupun 
dari pengalaman guna memperkuat dalil dalam persidangan. Ketika MK berpendapat sidang sudah cukup untuk dasar pembuatan putusan, maka MK akan Rapat Permustawaratan Hakim dan menjadwalkan pembacaan putusan. Sesudah MK membacakan Putusan dalam persidangan yang terbuka untuk umum, para pihak akan mendapatkan Salinan Putusan dari Panitera MK.

Putusan PHPU yang dibacakan dalam sidang yang digelar terbuka untuk umum, amarnya berdasarkan ketentuan Pasal 14 PMK No.14 Tahun 2008 jo Pasal 13 PMK No.15 Tahun 2008 jo Pasal 15 PMK No.16 Tahun 2009 jo Pasal 15 PMK No.17 Tahun 2009 berbunyi: tidak dapat diterima; dikabulkan; dan ditolak. Pernah terjadi Pemohon yang menarik permohonannya sebagaimana yang diatur Pasal 35 UU MK, maka akan dikeluarkan penetapan Hakim. Berdasarkan Pasal 35 UU MK, Penetapan adalah tindakan Badan Peradilan diluar putusan, sama seperti penetapan hari sidang dan lain-lain selain vonis hakim. Penarikan tersebut berimplikasi permohonan tidak bisa diajukan kembali ke MK. Putusan MK dalam perkara PHPU sifatnya final and binding. Dalam Persidangan MK tidak dikenal verzet penetapan MK seperti dalam Hukum Acara Perdata, seperti verzet terhadap waktu sidang, pencabutan gugatan, penetapan lampau waktu gugatan, dan sebagainya.

Peserta pada kegiatan ini berjumlah 30 Peserta. Mengingat kondisi saat itu memasuki masa New Normal dampak dari Pandemi COVID-19. Kegiatan dilakukan dengan mengedepankan Protokol Kesehatan. Kegiatan ini ditujukan untuk memberikan pemahaman kepada Peserta tentang Mekanisme PHPU; Memberi pemahaman kepada Peserta tentang halhal update tentang Pembuktian dalam Hukum Acara PHPU; dan Khusus Dosen sebagai sarana Pengabdian Kepada Masyarakat yang merupakan unsur Tri Dharma Perguruan Tinggi.

Tabel 1. Hasil Kuisioner

\begin{tabular}{|c|c|c|c|}
\hline No & Unsur & Pra Pengabdian & Pasca Pengabdian \\
\hline 1 & $\begin{array}{l}\text { Pembuktian dalam Hukum } \\
\text { Acara Perselisihan Hasil Pemilu }\end{array}$ & $\begin{array}{l}\text { Belum terlalu memahami dan } \\
\text { mengerti Pembuktian dalam Hukum } \\
\text { Acara Perselisihan Hasil Pemilu }\end{array}$ & $\begin{array}{l}\text { Sudah memahami dan } \\
\text { mengerti Pembuktian } \\
\text { dalam Hukum Acara } \\
\text { Perselisihan Hasil } \\
\text { Pemilu }\end{array}$ \\
\hline 2 & $\begin{array}{l}\text { Alat Bukti dalam Hukum Acara } \\
\text { Perselisihan Hasil Pemilu }\end{array}$ & $\begin{array}{l}\text { Belum memahami dan mengerti Alat } \\
\text { Bukti dalam Hukum Acara } \\
\text { Perselisihan Hasil Pemilu }\end{array}$ & $\begin{array}{l}\text { Sudah memahami dan } \\
\text { mengerti Alat Bukti } \\
\text { dalam Hukum Acara } \\
\text { Perselisihan Hasil } \\
\text { Pemilu }\end{array}$ \\
\hline
\end{tabular}

Sumber: Hasil Pelaksanaan (2020)

Kegiatan pengabdian kepada masyarakat dalam bentuk Pelatihan Pembuktian PHPU di MK berjalan dengan baik dan lancar. Mitra PKM ini ikut membantu dalam mempersiapkan 
segala kebutuhan kegiatan, mulai dari tempat, personel hingga peserta yang ikut serta dalam kegiatan ini. Peserta kegiatan terdiri dari unsur Komunitas Republik Celoteh Hukum (RECEH); Organisasi Mahasiswa Intra dan Ekstra Kampus di Kota Bengkulu; Organisasi Kepemudaan Bengkulu; dan Organisasi Pemuda Daerah Bengkulu.
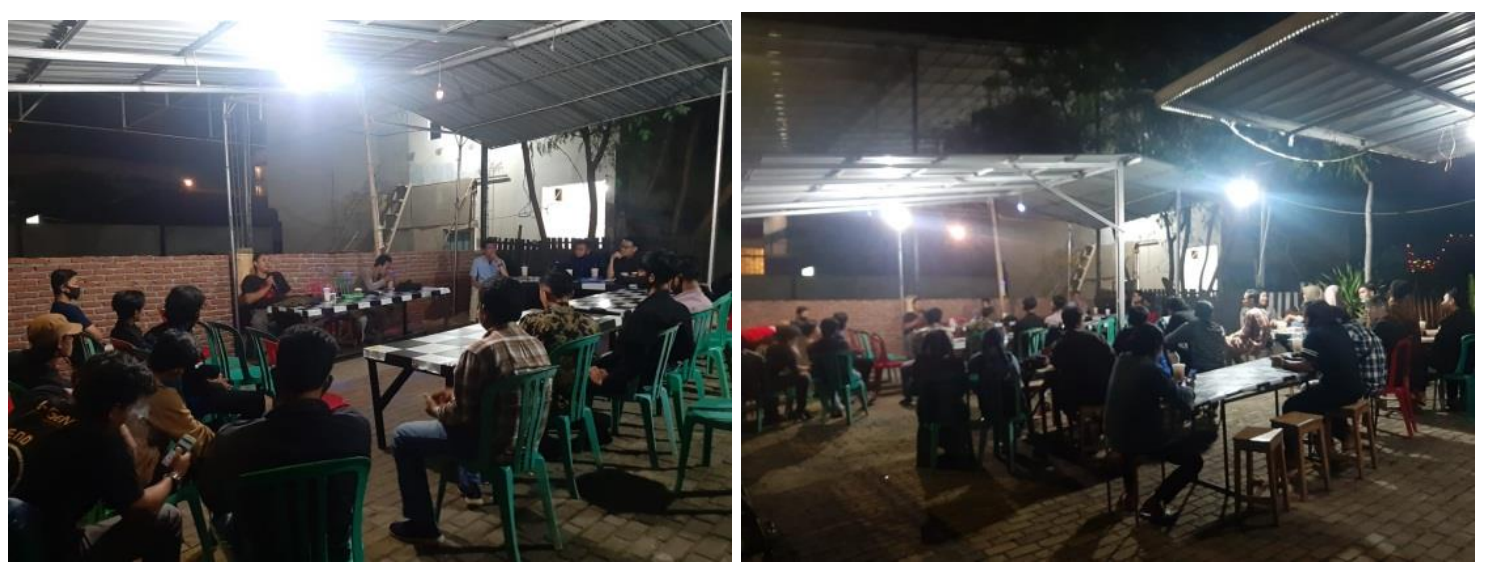

Sumber: Hasil Pelaksanaan (2020)

Gambar 1. Presentasi Tim Pengabdi

Pelatihan ini diawali dengan perkenalan tim pengabdi yang merupakan Dosen Bagian Hukum Administrasi dan Ketatanegaraan Fakultas Hukum Universitas Bengkulu, yang terdiri dari: 1). Dr. Amancik, S.H., M.Hum yang juga merupakan Dekan FH UNIB); 2). Putra Perdana Ahmad Saifulloh, S.H., M.H: 3). Beni Kurnia Illahi, S.H., M.H; 4). Sonia Ivana Barus, S.H., M.H dan didampingi Mahasiswa Pendamping, Dimas Septian Wijaya yang juga menjadi Moderator selama kegiatan ini berlangsung. Pengabdi melibatkan Mahasiswa dimaksudkan agar mahasiswa dapat ambil bagian dan terlibat langsung dalam hal mensosialisasikan peraturanperaturan yang berlaku. Di samping itu, pengalaman dan pengamalan ilmu dapat secara langsung mereka terapkan, sehingga kemajuan dalam bidang akademik akan jauh lebih terasa dimanapun para mahasiswa akan ikut mendalami materi-materi yang akan disampaikan.

Pengabdi terlebih dahulu memperkenalkan diri dilanjutkan dengan penyebaran kuesioner pre-test tentang Pembuktian PHPU di MK, guna mengetahui pengetahuan dasar peserta akan hal tersebut. Selama kegiatan berlangsung, tampak peserta sangat antusias mendengarkan paparan materi penyuluhan. Pemaparan materi dilaksanakan selama 40 menit dan dilanjutkan dengan sesi tanya jawab interaktif di akhir paparan. Antusiasme peserta dalam kegiatan ini terlihat dari pertanyaan-pertanyaan yang muncul untuk kemudian disampaikan jawabannya oleh pemateri. Di penghujung kegiatan penyuluhan ini, pengabdi kembali menyebarkan kuesioner post-test untuk mengetahui sejauh mana tingkat pemahaman dan pertambahan pengetahuan peserta akan Pembuktian PHPU di MK. 
Dari hasil pelatihan, peserta dapat mengerti dan memahami ketentuan mengenai Pembuktian PHPU di MK. Antusiasme hadirin juga terlihat dari pertanyaan-pertanyaan yang muncul dalam sesi tanya jawab, antara lain: a. Apakah Alat bukti Surat yang dikatakan sebagai primary evidence tidak terbukti, maka MK Apakah MK akan mengabaikan alat bukti lainnya; $b$. Bagaimana membuktikan terjadinya kecurangan Pemilu dalam speedy trial yang hanya 14 hari; c. Apakah Ahli Hukum Pidana boleh menjadi Ahli di MK dan pertanyaan lainnya.
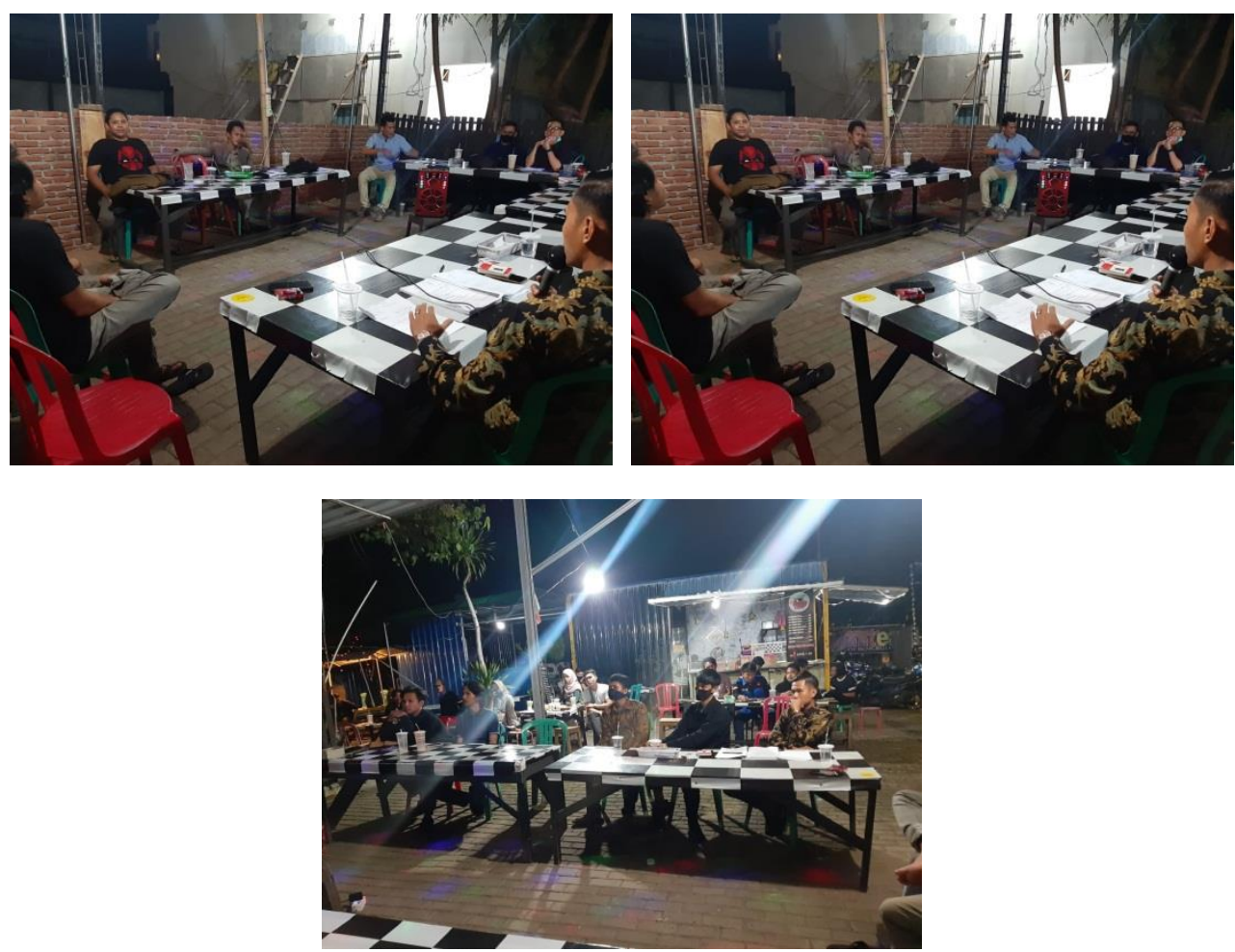

Sumber: Hasil Pelaksanaan (2020)

Gambar 2. Diskusi dan Tanya Jawab dengan Peserta

\section{Kesimpulan}

Melalui kegiatan ini, utamanya pada kegiatan pelatihan hukum acara PHPU, mitra menjadi lebih memahami tentang tata cara mekanisme, pembuktian dan dinamika pelatihan hukum acara perselisihan hasil pemilu yang sesuai dengan Hukum Positif. Diharapkan Pihak Masyarakat yang ingin memahami permasalahan hukum meminta ke LPPM, baik Perguruan Tinggi Negeri dan Swasta untuk memberi pelatihan dan penyuluhan ke Pihak Masyarakat karena ini merupakan hubungan simbiosis mutualisme dimana ada dua pihak yang saling diuntungkan. Untuk Pihak Masyarakat agar memahami hukum sesuai dengan peraturanperundang-undangan, teori, asas, dan praktik di lapangan. Untuk Dosen yang diberi tugas 
LPPM akan mendapatkan point Pengabdian Kepada Masyarakat yang merupakan bagian dari Tri Dharma Perguruan Tinggi.

\section{Ucapan Terima Kasih (Opsional)}

Penulis mengucapkan terima kasih sebesar-besarnya kepada: 1). LPPM UNIB yang memberi kami Surat Tugas untuk melaksanakan Pengabdian Kepada Masyarakat yang merupakan bagian dari Tri Dharma Perguruan Tinggi; 2). Komunitas Republik Cerdas Hukum (RECEH) yang menjadi Mitra dalam PKM ini terdiri dari anak-anak muda potensial dan kritis; 3). para peserta yang terdiri dari Organisasi Mahasiswa Intra dan Ekstra Kampus di Kota Bengkulu; Organisasi Kepemudaan Bengkulu; dan Organisasi Pemuda Daerah Bengkulu yang luar biasa semangat belajar dan ingin tahunya untuk memahami permasalahan hukum kontemporer.

\section{Daftar Pustaka}

Ansori. (2017). Legalitas Hukum Komisi Pemilihan Umum Daerah dalam Menyelenggarakan Pilkada The Legality of Regional Election Regional Head Election. Jurnal Konstitusi, 14(3), 553-572. http://ejournal.mahkamahkonstitusi.go.id/index.php/jk/index

Bambang Sutiyoso, \& Sri Hastuti Puspitasari. (2005). Aspek-Aspek Perkembangan Kekuasaan Kehakiman di Indonesia. UII Press.

Gubernur, W. (2016). Ekstensifikasi Subjectum Litis dalam Perselisihan Pemilu Legislatif dan Pemilihan Kepala Daerah. Konstitusi.

Iza Rumesten RS. (2014). Dilema dan Akibat Hukum Putusan Mahkamah Konstitusi Mengenai Kewenangan Memutus Sengketa Pilkada. Jurnal Konstitusi, 11(4), 693-713.

Jimly Asshiddiqie. (2005). Pengantar Ilmu Hukum Tata Negara. Konstitusi Press.

Kosmas Ebu, dan Mauritsius, D. (2009). Pelaksanaan Asas Pemilu: Analisis Masalah Daftar Pemilih Tetap Dalam Pemilu,. Jurnal Konstitusi, Maret.

Kurniawan, W. (2011). Sengketa Pemilukada; Menegakkan Keadilan Dalam Hasil Dan Proses (Analisis Putusan MK Nomor 28/PHPU.D-VIII/2010 Tentang Pemilukada Kabupaten Gresik). Jurnal Konstitusi, 8(5), 803-828.

Ni'matul Huda. (2008). UUD 1945 dan Gagasan Amandemen Ulang. PT.Raja Grafindo Persada.

Seran, G. G. (2019). Konstitusionalitas dan Desain Pemilukada Langsung Serentak Nasional. Jurnal Konstitusi, 16(3), 655. https://doi.org/10.31078/jk16310

Supriyadi, \& Kasim, A. (2020). Desain Badan Peradilan Khusus Pemilihan Pasca Putusan Mahkamah Konstitusi Nomor 97/PUU-XI/2013. Jurnal Konstitusi, 17(September).

Tim Pengajar, H. A. M. K. (2019). Hukum Acara Konstitusi. Setjen dan Kepaniteraan MK RI. 